\title{
Regulation of Growth and Flowering in Tuberose with Application of Bio-Regulators
}

\author{
Sangram S. Dhumal*, Manpreet Kaur, Pradeep Dalave, Vishnu K. Garande, \\ Ravi D. Pawar and Shriram S. Ambad
}

Department of Horticulture, College of Agriculture, Kolhapur-416004, Maharashtra, India

*Corresponding author

\begin{abstract}
A B S T R A C T

\begin{tabular}{|c|}
\hline Keywords \\
\hline $\begin{array}{l}\text { Tuberose, Phule } \\
\text { Rajani, Bioregulators, } \\
\text { GA, IBA, Growth, } \\
\text { Flowering }\end{array}$ \\
\hline Article Info \\
\hline $\begin{array}{l}\text { Accepted: } \\
10 \text { August } 2018 \\
\text { Available Online: } \\
10 \text { September } 2018\end{array}$ \\
\hline
\end{tabular}

The effect of different levels of $\mathrm{GA}_{3}(40,80,120$ and $160 \mathrm{ppm})$ and IBA $(20,40,60$ and $80 \mathrm{ppm}$ ) on the regulation of growth and flowering in Tuberose cv. Phule Rajani was studied. The bioregulators were applied as dip treatment of tuberose bulbs for $24 \mathrm{hrs}$ before planting and as a spray 30 day after planting. The application of bioregulators; soaking as well as spraying, was found to be effective in manipulating the growth and flowering traits as compared to control. Soaking of the tuberose bulbs in $160 \mathrm{ppm} \mathrm{GA}_{3}$ solution for 24 hours before planting significantly increased plant height $(53.73 \mathrm{~cm})$ with highest number of leaves per plant (33.17) and width of leaf $(23.97 \mathrm{~mm})$. It also registered minimum number of days for spike emergence (59.67). Significant increase in length of spike $(63.77 \mathrm{~cm})$ and rachis $(28.19 \mathrm{~cm})$, maximum number of spikes per plant (3.57), florets per spike (24.54), number of bulbs per plant (10.07), bulblets per plant (19.32), weight of bulbs per plant (194.62 gm) and highest vase life (9.87 days) was recorded in dipping treatment of tuberose bulbs in $160 \mathrm{ppm} \mathrm{GA}_{3}$ for 24 hours before planting which was followed by the treatments; spraying with $160 \mathrm{ppm} \mathrm{GA}_{3}$, soaking in $80 \mathrm{ppm} \mathrm{IBA}$ and spraying of $80 \mathrm{ppm}$ IBA 30 days after planting.
\end{abstract}

\section{Introduction}

Tuberose (Polianthes tuberosa L.), an ornamental bulbous plant, is commercially grown for its attractive and luring cut flowers in tropical and subtropical areas of country. It has an enormous economic potential for cut flower trade and essential oil industry. As per area and production statistics of the National Horticulture Board, the total area under tuberose cultivation in the country is about 7.95 lakh hectares. Tuberose planted at a spacing of $30 \times 30 \mathrm{~cm}$ with a plant population of 1,11,000 plants/ha yield about 90,000 marketable spikes and 1.8 lakhs flowering size bulbs. This traditional flower crop of Indiablooms throughout the year and its clustered spikes are rich in fragrance; florets are star shaped, waxy and loosely arranged on spike that can reach up to 30 to $45 \mathrm{~cm}$ in length. The spikes are useful as cut flowers in vase decoration and bouquets; while individual floret is used for making veni, garland, button-holes or crown. It has a delightful fragrance and is the source of tuberose oil. The natural flower oil of tuberose 
is one of the most expensive raw materials for perfume, thereby contributing in export earnings.

Increased demand for its cut-flower and aesthetic use has led to improvisation in cultural practices with sole aim of enhancing yield and quality of tuberose plant. Exogenous application of plant growth regulators is being practiced by the commercial growers as a part of cultural practice to improve the different economically important and market desirable characteristics of this flower plants. Sarkar et al., (2009) reported increased no. of bulb per plants, weight of individual bulb and total bulb yield when different growth regulators (NAA and IBA) were applied as dip treatment under north Indian conditions.GA $\mathrm{A}_{3}$ is the most effective plant growth regulator for growth and flowering of tuberose at a concentration of 300 ppm (Amin et al., 2016). Mukhopadhyay et al., (1983) found that the plant height was reduced with ethrel spray at high concentration and spike length and floret numbers per spike was increased with $\mathrm{GA}_{3}$ application under Bangalore conditions. Plant response to foliar application of plant growth regulators (PGRs) is often variable, in part due to environmental factors. High humidity and longer drying time often are also reported to increase PGR uptake in laboratory studies (Stover et al., 2005).

Therefore there is need to investigate the effective concentrations of PGR and their response under varied environmental conditions of country for optimizations of technique. This study entitled "effect of application of bio-regulators on growth and flowering of Tuberose var. 'Phule Rajani' was carried out at the field of Horticulture section, college of Agriculture Kolhapur where average temperature varies between $23^{\circ} \mathrm{C}$ to $31^{\circ} \mathrm{C}$ over the year. The objective of this study was to find the effect of bio-regulators on the regulation of growth and flowering in
Tuberose cv. Phule Rajani under Kolhapur conditions of Maharashtra state of India.

\section{Materials and Methods}

The experiment entitled "Effect of application of bio-regulators on growth and flowering of Tuberose var. 'Phule Rajani' " was carried out at the field of Horticulture section, college of Agriculture Kolhapur during the year 2009-10. Healthy bulbs of tuberose var. Phule Rajani of uniform size were planted at the spacing of 30 $x 30 \mathrm{~cm}$. The experiment was laid out in Randomized Block Design with three replications.

The soaking was done 24 hours before planting and spraying was done 30 days after planting. Tuberose varieties 'Phule Rajani was used for the study (2009-2010). The bulbs were procured from the Department of Horticulture, MPKV, Rahuri MH. Healthy Bulb sized about $2.0 \mathrm{~cm}$ were used as planting material. The chemicals used in experiment were gibberellic acid $\left(\mathrm{GA}_{3}\right)$ and indole-3butryric acid (IBA).The experiment considered 17 treatment of soaking and spraying of $\mathrm{GA}_{3}$ and IBA respectively. The treatments comprise four levels of $\mathrm{GA}_{3}$ (40, 80,120 and $160 \mathrm{ppm}$ ) and four levels of IBA (20, 40, 60 and 80 ppm) respectively. Sufficient volume of a particular growth regulator solution was used for soaking of bulb and then bulbs were dried overnight under ambient conditions before planting. Different parameters were recorded pertaining to growth, flowering and bulb production.

\section{Results and Discussion}

\section{Effect of $\mathrm{GA}_{3}$ and IBA on vegetative growth}

Data presented in Table 1, showed increased height, no of leaves per plant, and width of leaf with different concentrations of growth regulators when compared with control. The 
maximum number of leaves per plant (33.17), plant height (53.73), and width of leaf (23.97) was recorded with soaking treatment at 180ppmfollowed by spraying of $160 \mathrm{ppm} \mathrm{GA}$ in the cultivar Phule Rajni. $\mathrm{GA}_{3}$ has been applied to improve various characteristics in tuberose plant including the plant height [Shankar et al., (2010); Kumar and Gautam, (2011) and Amin et al., (2011)] and number of leaves [Shradha et al., (2002) and Singh, (1999)]. The effect of gibberellins on growth characteristics may be due to the cell elongation and rapid cell stimulation in the bulbs and increasing auxin level of tissue or enhance the conversion of tryptophan to IAA which causes the cell division and cell elongation [(Amin et al., (2011)].

Minimum day (59.42) for spike emergence was recorded from spraying $\mathrm{GA}_{3}$ at $160 \mathrm{ppm}$ concentration. Soaking bulb in $\mathrm{GA}_{3}$ at 180 ppm concentration recorded maximum spike length $(63.77 \mathrm{~cm})$ which was in significance with control $(57.71 \mathrm{~cm})$ (Table. 1). These results were in accordance with the findings of Jana and Biswas (1979) and Mukhopadhyay and Bankar (9) in tuberose; and Bhattacharjee (3) in gladiolus. Increased cell division and elongation as accelerated by PGR application might resulted in increased spike length as reported by Shanker et al., (2010) and Tiwari and Singh (2002) in tuberose.

Maximum rachis length was obtained with $\mathrm{GA}_{3}$ at concentration of $180 \mathrm{ppm}$ which was in conformity with Devadanam et al., (2005).

Table.1 Effect of application of bio-regulators on growth characteristics

Tuberose var. 'Phule Rajni'

\begin{tabular}{|l|l|l|l|l|l|l|}
\hline Treatments & $\begin{array}{l}\text { Leaves per } \\
\text { plant }\end{array}$ & $\begin{array}{l}\text { Height of } \\
\text { plant } \\
(\mathbf{c m})\end{array}$ & $\begin{array}{l}\text { Width of } \\
\text { leaf }(\mathbf{m m})\end{array}$ & $\begin{array}{l}\text { Days } \\
\text { spike } \\
\text { emergence }\end{array}$ & $\begin{array}{l}\text { Length of } \\
\text { spike } \\
(\mathbf{c m})\end{array}$ & $\begin{array}{l}\text { Length } \\
\text { rachis }\end{array}$ \\
\hline$T_{1-\text { Control }}$
\end{tabular}


Table.2 Effect of application of bio-regulators on floral attributes of Tuberose var. 'Phule Rajni'

\begin{tabular}{|c|c|c|c|c|c|c|}
\hline Treatments & $\begin{array}{l}\text { Spikes per } \\
\text { plant }\end{array}$ & $\begin{array}{c}\text { Florets } \\
\text { per spike }\end{array}$ & $\begin{array}{l}\text { Vase life } \\
\text { (Days) }\end{array}$ & $\begin{array}{c}\text { Bulbs per } \\
\text { plant }\end{array}$ & $\begin{array}{l}\text { Bulblets } \\
\text { per plant }\end{array}$ & $\begin{array}{c}\text { Wt. of } \\
\text { bulbs per } \\
\text { plant }\end{array}$ \\
\hline$T_{1-\text { Control }}$ & 1.67 & 19.33 & 7.34 & 5.76 & 11.56 & 125.32 \\
\hline$T_{2-\text { GA3 }} 40 \mathrm{ppm}$ & 2.34 & 20.89 & 8.37 & 7.89 & 14.67 & 153.76 \\
\hline$T_{\text {3- GA3 } 80 \mathrm{ppm}}$ & 2.87 & 22.79 & 9.07 & 9.23 & 17.22 & 162.17 \\
\hline$T_{4-G A 3120} \mathrm{ppm}$ & 3.18 & 22.16 & 9.19 & 9.74 & 18.01 & 181.89 \\
\hline$T_{5-\text { GA3 } 180 \mathrm{ppm}}$ & 3.57 & 24.54 & 9.87 & 10.07 & 19.32 & 194.62 \\
\hline $\mathrm{T}_{6-\text { IBA } 20 \mathrm{ppm}}$ & 2.13 & 21.98 & 8.68 & 7.13 & 13.87 & 149.89 \\
\hline$T_{7-\text { IBA }} 40 \mathrm{ppm}$ & 2.24 & 21.67 & 8.32 & 8.22 & 15.11 & 161.78 \\
\hline 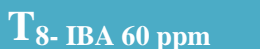 & 2.31 & 22.47 & 8.66 & 8.87 & 16.02 & 167.12 \\
\hline T9- IBA $80 \mathrm{ppm}$ & 2.37 & 23.82 & 9.09 & 9.33 & 17.94 & 171.81 \\
\hline$T_{10-\text { GA3 }} 40 \mathrm{ppm}$ & 2.18 & 21.33 & 8.38 & 6.87 & 13.33 & 157.98 \\
\hline$T_{11-\text { GA3 } 80 \mathrm{ppm}}$ & 2.43 & 22.18 & 8.67 & 7.54 & 14.05 & 165.09 \\
\hline 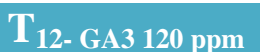 & 2.61 & 23.97 & 9.34 & 7.37 & 14.55 & 179.93 \\
\hline $\mathrm{T}_{13-\mathrm{GA}} 160 \mathrm{ppm}$ & 3.29 & 24.18 & 9.69 & 9.97 & 19.01 & 189.11 \\
\hline $\mathrm{T}_{14-\text { IBA } 20 \mathrm{ppm}}$ & 2.04 & 21.37 & 8.37 & 6.02 & 13.09 & 139.98 \\
\hline 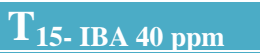 & 2.18 & 22.34 & 8.77 & 6.11 & 13.37 & 142.63 \\
\hline$T_{16-I B A} 60 \mathrm{ppm}$ & 2.39 & 22.61 & 8.88 & 7.23 & 13.92 & 159.88 \\
\hline$T_{17-\text { IBA } 80 ~ p p m}$ & 2.41 & 23.67 & 9.04 & 8.94 & 14.72 & 168.91 \\
\hline 'F' test & Sig. & Sig. & Sig. & Sig. & Sig. & Sig. \\
\hline $\mathrm{SE}(\mathrm{m})+$ & 0.017 & 0.375 & 0.267 & 0.249 & 0.374 & 2.361 \\
\hline CD at $5 \%$ & 0.052 & 1.137 & 0.811 & 0.755 & 1.134 & 7.154 \\
\hline
\end{tabular}

\section{Effect of $\mathrm{GA}_{3}$ and IBA on flowering}

Significant improvement was observed in floral and bulb characteristics viz. spikes per plant, florets per spike, vase life, bulbs per plant, bulblets per plant and weight of bulbs per plant after PGR application when compared with control. Maximum numbers of spike per plant were registered with soaking bulbs in GA 180 ppm which was statistically identical with spraying GA 160 ppm.

Maximum no. of floret per spike (24.54) was observed at $180 \mathrm{ppm}$ soaking of GA and the minimum number of floret/ spike (19.33) in control treatment. Among the different PGR applications, $\mathrm{GA}_{3}$ treatmentat 160ppmshowed the highest vase life of 9.67 days which was in accordance with Mukhopadhyay and Bankar
(1983). The favorable effect of $\mathrm{GA}_{3}$ might be due to the fact that it accelerates carbohydrate accumulation and increases metabolic activities in the plants as reported by Singh et al., (2003)

The number of bulbs and bulblets per plant of tuberose significantly affected with growth regulators used in this study. High level of $\mathrm{GA}_{3}$ application led to increase in no. of bulb, bulblet and weight of bulb per plant. The maximum number of bulbs per plant (10.7) was recorded at $180 \mathrm{ppm} \mathrm{GA}_{3}$ dip treatment followed by soaking of bulb in $\mathrm{GA}_{3}$ application at $160 \mathrm{ppm}$. Bulblets per plant (19.32) and weight of bulb per plant (194.62) were also maximum at 180ppm $\mathrm{GA}_{3}$ treatment. Similar results were reported by Mukhopadhyay and Bankar (1983) and Tonecki et al., (1979) in gladiolus and Sarkar et al., (2009) in tuberose (Table 2). 
Soaking treatment with $\mathrm{GA}_{3}$ at 180ppm significantly improved the different growth and floral characteristics in tuberose over the other PGR treatments studied in this experiment. Soaking treatment at $180 \mathrm{ppm}$ was found statistical identical with spraying treatment of $\mathrm{GA}_{3}$ at $160 \mathrm{ppm}$ for most of the studied floral and bulb parameters.

\section{References}

Amin, M.R., Pervin, N., Nusrat, A., Mehraj, H. and Jamal Uddin, A.F.M. (2017). Effect of plant growth regulators on growth and flowering of tuberose (Polianthes tuberosa L.) cv. single. J. of Biosci Agri. Res., 12(01), 1016-1020.

Bhattacharjee, S.K. (1983). Influence of growth regulating chemicals on Hippeastrumhybridum. Hort. Gdns. Bull. 36: 237-42.

Devadanam, A., Shinde, B. N., Sable, P. B. and Vedpathak, S. G. (2005). Effect of foliar spray of plant growth regulators on flowering and vase life of tuberose (Polianthes tuberose L.). J. Soils and crops, 17(1), 86-88.

Dhua, R.S., S.K. Ghosh, S.K. Mitra, L.P. Yadav and T.K. Bose, 1978. Effect of bulb size, temperature treatment of bulb and chemicals on growth and flower production of tuberose (Polianthus tuberosa L.) Acta Hort., No., 205, pp. 121-128.

Indian Horticulture database (2014). http://nhb.gov.in.

Jana, B.K. and S. Biswas (1979). Effect of growth substances on growth and flowering of tuberose (Polianthus tuberosa L.) Haryana J. of Hort. Sci., 8 (3-4): 216-219.
Kumar, A. and Gautam, D. K. (2011). Effect of plant growth regulators on spike yield and bulb production of tuberose (Polianthes tuberosa Linn.) cv. "Hyderabad Double". Progressive Hort., 43(2): 234-236.

Mukhopadhyay, A. and Banker, G.L. (1983).Regulation of growth and flowering in tuberose. J.Orn. Hort. 6: 8081.

Sarkar, J., Mishra, R.L., Singh, S.K., Prasad, K.V., Arora, A. (2009). Effect of growth regulators on growth and flowering in tuberose under north India conditions. Ind J. Hort. 66(4): 502- 507.

Shanker, K., Singh, A. K. and Singh, H. K. (2010). Effect of plant growth regulators on spike yield and bulb production of tuberose double. Plant Archives, 11(1), 169-171.

Shradha, G., Belorkar, P. and Mohariya, V. (2002). Effect of bulb soaking, foliar spray of GA3 on growth, flowering, and yield of tuberose. J. Soil Crops, 12:105-7.

Singh, A.K. 1999. Effect of growth regulators ongrowth and flowering of tuberose. Acta Hort.526:225-27.

Singh, P.V., S. Panwar and J. Kumar (2003). Response of tuberose to plant growth regulators. J. Orn Hort. Vol. 6 (1): 80-81.

Stover, E.W. and D.W. Greene. (2005). Environmental effects on the performance of foliar applied plant growth regulators: A review focusing on tree fruits. Hort Technology 15:214-221.

Tiwari, J. K. and Singh, R. P. (2002). Effect of preplanting GA3 treatment on tuberose. $J$. Orn. Hort. 5(2), 44-55.

Tonecki, J. (1979). Effect of growth substances on shoot apex differentiation and changes in sugars and free amino acids in gladiolus. Acta Hort., No. 109, pp. 347355 .

\section{How to cite this article:}

Sangram S. Dhumal, Manpreet Kaur, Pradeep Dalave, Vishnu K. Garande, Ravi D. Pawar and Shriram S. Ambad. 2018. Regulation of Growth and Flowering in Tuberose with Application of Bio-Regulators. Int.J.Curr.Microbiol.App.Sci. 7(09): 1622-1626.

doi: https://doi.org/10.20546/ijcmas.2018.709.194 